Disponível em

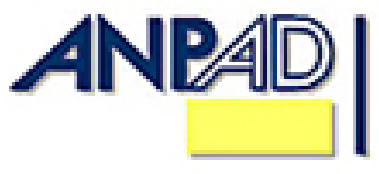

http://www.anpad.org.br/rac

RAC, Rio de Janeiro, v. 17, n. 6, art. 4, pp. 704-719, Nov./Dez. 2013

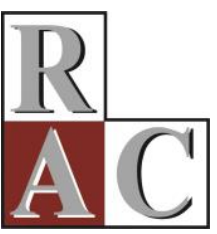

\title{
Analyzing Local Government Financial Performance: Evidence from Brazilian Municipalities 2005-2008
}

Ricardo Correa Gomes

E-mail: rgomes@unb.br

Universidade de Brasília - PPGA/UnB

Campus Universitário Darcy Ribeiro, ICC Norte, Subsolo, Módulo 25, 70910-900, Brasília, DF, Brasil.

Solange Alfinito

E-mail: solange.alfinito@gmail.com Universidade de Brasília - PPGA/UnB Campus Universitário Darcy Ribeiro, ICC Norte, Subsolo, Módulo 25, 70910-900, Brasília, DF, Brasil.

Pedro Henrique Melo Albuquerque E-mail: pedro.melo.albuquerque@gmail.com

Universidade de Brasília - UnB Campus Universitário Darcy Ribeiro, ICC Norte, Subsolo, Módulo 25, 70910-900, Brasília, DF, Brasil. 


\title{
Resumo
}

O tamanho das cidades tem se tornado um problema desde a aceitação da doutrina da Nova Gestão Pública, que sugeriu a desagregação de estruturas em unidades gerenciáveis. Em alguns países, existe um grande número de cidades pequenas que se sustentam, quase que exclusivamente, com transferências intergovernamentais. Este artigo pretende contribuir com a literatura sobre gerenciamento do desempenho de organizações públicas com a apresentação de evidências empíricas sobre os fatores determinantes do desempenho financeiro desse tipo de organizações. Os dados advêm de uma amostra de cidades brasileiras, e se referem ao período de 2005 a 2008 . A principal descoberta da pesquisa está relacionada com a conclusão de que cidades maiores teriam melhores condições de gerenciar recursos financeiros, estando aptas a aumentar as receitas e a controlar despesas do que cidades menores, e esse fato apresenta uma contribuição importante para a discussão entre fusão e fragmentação de cidades. Em cidades menores, os prefeitos possuem condições menos favoráveis de aumentar a arrecadação dos impostos e de reduzir despesas, o que torna suas administrações vulneráveis pela dependência de recursos externos. Uma outra contribuição se refere ao fato de que a qualificação pessoal do prefeito, em um regime no qual todas as decisões estão centralizadas em uma só pessoa, exerce efeito insignificante sobre o desempenho financeiro da prefeitura.

Palavras-chave: governo local; desempenho financeiro; tamanho de cidades; municípios brasileiros.

\begin{abstract}
Municipality size has become an issue since the New Public Management doctrine of disaggregating structures into manageable units. In some countries, this doctrine led to the creation of small-scale agencies relying heavily upon transfers from upper-level governments. This paper aims to contribute to performance management literature by providing empirical evidence about some determinant factors that are likely to endow local governments with superior financial performance. Data came from a sample of Brazilian municipalities and refers to the period 2005-2008. The main conclusion of this investigation is that larger cities are more likely to manage revenue and expenditure better than are smaller cities, which aligns with the discussion of amalgamation versus fragmentation. This conclusion stems from the findings that in small municipalities mayors have fewer conditions to improve financial performance due to the difficulty of raising and collecting taxes and of reducing expenditures, which makes their administrations far more dependent upon external sources of money. Therefore, this dependent relationship can be seen as the cause of poor financial performance to the extent that it lowers mayoral discretion when making decisions. Another contribution this paper proposes to theory and practice relates to the fact that in the strong-mayor form of local government, mayoral qualification is likely to have little effect upon performance.
\end{abstract}

Key words: local government; financial performance; population size; Brazilian Municipalities. 


\section{Introduction}

Scholars have dedicated a great deal of time and effort to finding the determinant factors likely to improve the performance of public organizations (Andrews, Boyne, \& Walker, 2011). There are several dimensions that frame public managers' actions to promote superior performance, as indicated by Rainey and Steinbauer (1999), Boyne (2003), Vilkinas, Cartan and Piron (1994), Brewer (2005), Moynihan and Pandey (2005), and O'Toole and Meier (1999). In spite of the number and variety of studies that have been undertaken, we still don't know with certainty the whole set of independent variables that are likely to improve municipal government performance. When the focus is placed on developing countries the situation is more complex due to the political and administrative differences from developed countries.

In this paper we analyze the performance of a sample of Brazilian municipalities in terms of finance. As local governments are entitled to raise some taxes locally, specifically taxes on property and services (Hoene \& Pagano, 2008), we created an index for measuring how efficient a given administration is at securing money for administrative expenditure on the municipality's operations. As a strong-mayor system of government (Mouritzen \& Svara, 2002), mayors are both political leaders and municipal managers and they are empowered to manage the municipality on a day-to-day basis, managing policies and resources, as well as dealing with political issues. We regard this issue as critical to the extent that the vast majority of Brazilian municipalities rely heavily on transfers from Federal and State governments (Martell, 2008; Mattos, Rocha, \& Arvate, 2011) in order to ensure fiscal equilibrium, which increases local government dependence on good relationships with upperlevel government for ensuring the flow of money (Fenno, 1966; Whitney, 2013) and, therefore, reducing mayors' managerial discretion (Meier \& Keiser, 1996). This also seems to be a typical case of the Flypaper Effect (Hamilton, 1986; Hines \& Thaler, 1995; Mattos et al., 2011), as money that comes from upper-level government grants increase local government expenditure more than the money that comes from taxpayers' personal incomes. According to Inman (2008, p. 1), "an extra dollar of personal income increased government spending on the order of $\$ 0.02$ to $\$ 0.05$ but an equivalent extra dollar of grants-in-aid increased government spending by $\$ 0.30$ to often as much as a full dollar". Mayors take the transfer of funds from other levels of government for granted, and federal governments use this as a means for improving economic conditions (Bailey \& Connolly, 1998). We contend that the higher the percentage of taxes a mayor is able to raise locally, the lower the level of dependence and reliance on transfers from other levels of government and the greater the autonomy of the mayor, and, therefore, the higher the discretion for making decisions. As independent variables we used mayoral quality (represented by age, educational level and previous government experience), and population size. As a control variable, we used ideology (whether the political party the mayor is affiliated to is regarded as to the left or to the right).

The paper is structured as follows. In the next section we briefly present the Brazilian local government system and the importance of the mayor's role in managing resources and delivering services to the local population. In the following section we discuss the theories underpinning the choice of dependent and independent variables for the creation of the hypotheses. This is followed by the methods employed in the investigation, and a discussion of results of the analysis. The paper ends with conclusions and the prospects for further work based on the present study.

\section{The Brazilian System of Local Government}

In terms of the framework for analyzing local government developed by Mouritzen and Svara (2002), Brazil adopts the strong-mayor form, where mayors act as both political leaders and managers; i.e. the mayor is in charge of the whole set of decisions involving the daily activities of the local government, as well as managing contacts and negotiations with the State and Federal 
Governments, other bodies of government and wider society. At the same time as he/she deals with the Municipal Chamber (local legislative power) for approving laws and fights with the Federal and State Government for more resources, he/she is involved in the daily activities of managing the resources the municipality needs to operate.

Brazil has a federal political system (Watts, 1998) and after the 1988 Federal Constitution adopted Fiscal Federalism, in which municipalities are regarded as autonomous entities (Watts, 1998); i.e. they are entitled to have a constitution (labeled as the Organic Law), and to collect some taxes locally, specifically property and services tax, and other sources of contributions (Selcher, 1998). In a Brazilian municipality, these are the main sources of local income over which the mayor has some discretion (Selcher, 1998).

At the present time, Brazil has 5,565 municipalities, whose population ranges from around 1,000 up to 11,000,000 inhabitants (the capital city of São Paulo) (Instituto Brasileiro de Geografia e Estatística [IBGE], 2011). It is worth mentioning that since the 1988 Federal Constitution, the number of Brazilian municipalities has greatly increased (Dahlby, 2011). The size of the municipalities can be represented as a skewed distribution with positive asymmetry, as most municipalities are smaller than 50,000 inhabitants. The variety in terms of size means that municipalities are unequal in terms of their capacity to raise money in the form of taxes. For example, large cities are more likely to raise more money from both property and service taxes than are small cities, due to economies of scale (Shapiro, 1963).

In Brazil, mayors are elected for a four-year political mandate and elections do not coincide with those for the president and governors. Municipal elections were held in 2004, 2008, and 2012, while presidential elections occurred in 2002, 2006, and 2010.

In terms of revenue, Brazilian Municipalities have several sources, which are composed of locally taxes collected, contributions, fares, and transfers from Federal and State Governments, but the greatest source of transfers is the Municipal Participation Fund (MPF) (Mattos et al., 2011, p. 247), which is distributed according to the following formula: "The MPF resources go 10\% to the state capitals, $86.4 \%$ to the countryside municipalities and the remainder is shared among the countryside municipalities with more than 142,633 inhabitants". The amount of money a given municipality receives from the MPF is defined by two factors, namely population and per capita incomes. As population and per capita factors are likely to change from one period to another, there is room for negotiation between mayors and upper-level governments in order to mitigate this fact. Due to the importance of the negotiation between mayors and Federal Government officers, in which the most important cities are likely to take advantage of their position, the amount of money can change according to the political importance of the municipality (Mattos et al., 2011).

\section{Determinants of Performance}

Rainey and Steinbauer (1999) proposed a framework that contains a set of factors likely to explain the effectiveness of public agencies. These factors are support and control from external stakeholders, resource availability, organizational culture, leadership, mission valence, and task design. In the same line of thinking, Boyne (2003) proposed that public services performance is likely to be explained by the amount of resources, regulation, differences in market competition, organizational factors, and management. The question that still remains is whether we need to deal with these predictor factors together, or is it possible to identify the individual contribution of each factor to performance?

In terms of managing performance, finance is a resource and, therefore, also very likely to be an end in the performance management framework. As a main assumption of this investigation, we contended that by wisely managing financial resources, managers are more likely to improve the 
quality of services provided to the public. Some studies associate high quality financial management with several dimensions of performance (Ogden \& Watson, 1999; Stanwick \& Stanwick, 1998; Waddock \& Smith, 2000). This makes it reasonable to assume that good financial management is a determinant factor of superior organizational performance.

According to Zafra-Gómez, López-Hernández and Hernández-Bastida (2009), there are several ways for assessing local government financial conditions, but assets and liabilities are to be taken into account in order to assess sustainability, flexibility and vulnerability. The authors particularly stress the importance of vulnerability as "an organization's level of dependence on external funding received via transfers and grants" (Bohte, 2001, p. 154). The greater the dependence on external funds, the higher the level of dependence and the lower the level of discretion (Pfeffer \& Salancik, 2003) for making decisions and for devising policies. In the same line of thinking, (Kloot, 1999, p. 239) recommended "debt reduction strategies to demonstrate responsible financial management: "never to be in the red'; infrastructure and asset management; and long-term economic and social sustainability" as managerial drivers for local governments. Corroborating the idea that sustainability is associated with performance, Mogues and Benin (2012) found out that external grants discourage local government efforts to raise revenue locally. Another way of assessing government financial performance relates to the fiscal health of the city in terms of the risk of bankruptcy, which according to Whitney (2013, p. 191), is the result of "budgetary mismanagement coupled with rising pension and debt costs". In the United States there are several cases of cities that have declared bankruptcy in order to have "the time and fiscal breathing room required to develop and negotiate plans for reorganizing debt while protecting government from its creditors" (Whitney, 2013, p. 186).

In this vein, vulnerability seems to be a feasible mean for assessing municipality performance. This raises the question of what should be regarded as determinant factors of superior financial performance in the case of municipalities. Approaching the question with the framework presented above, superior financial performance ought to be determined by some combination of resources and skills. Below, we suggest some sources of financial performance in local governments.

\section{Mayoral qualifications}

According to the extant literature, leaders have the means to influence followers' performance (Besley, Montalvo, \& Reynal-Querol, 2011; Lynn, 1996; Pfeffer \& Salancik, 2003). Cognitive resource theory contends that experienced and educated leaders are more likely to produce better plans and make better decisions than others (Fiedler, 1986). In the same line of thinking, leadership theory suggests "heterogeneity among leaders' educational attainment is important with growth being higher by having leaders who are more highly educated" (Besley et al., 2011, p. 205).

Avellaneda (2009) used educational background and job-related experience for measuring mayoral qualifications. She assumed that, "Education, for instance, generates confidence in decision making, and this confidence extends toward subalterns, who recognize their manager's abilities" (Avellaneda, 2009, p. 289). This assumption is coherent with the findings of Hambrick and Mason (1984), who suggested an association between formal education and performance. From this assumption, we propose the following hypothesis:

H1. Municipal financial performance is positively associated with the mayor's educational background.

In addition to educational background, a mayor's previous experience can also add value to his/her performance as a result of knowledge gathered throughout his or her lifetime. Hambrick and Mason (1984) suggested the importance of age as a factor in performance. According to them, younger managers are more likely to take risks, while older managers are more inclined to "seek more information, to evaluate information accurately, and to take longer to make decisions" (Hambrick \& Mason, 1984, p. 198). From this assumption, we develop the following hypothesis: 
H2. Municipal financial performance is positively associated with the mayor's age.

Taylor (1975) also stressed the importance of previous experience. According to him, "Years of experience in management was positively correlated with accuracy in judging the information value, time required to reach decisions, and the flexibility with which decisions are held" (Taylor, 1975, p. 79). This would suggests that having more life experience than younger managers, and having occupied administrative posts in local government administration, experienced managers can be expected to make wiser decisions than younger managers make. From this assumption, we propose the following hypothesis:

H3. Municipal financial performance is positively associated with the mayor's previous administrative experience.

\section{Population size}

Another issue in performance management is related to organization size, because of control over resources and economies of scale (Boyne, 1995, 1996a, 1996b; Shapiro, 1963). In the case of municipality size this discussion has been on the agenda for a long time (Borukhov, 1975). The idea of size as determinant to performance stems from the New Public Management doctrine in which public structures need to be disaggregated into smaller unities in order to be manageable (Hood, 1991). To this end, some studies are intended to understand the effects of amalgamation or fragmentation upon performance (Boyne, 1996a). Some also contended that the relationship between population size, costs, and public functions ought to be a curvilinear one (Carey, Srinivasan, \& Strauss, 1996; Stafford, 1963), making it possible to identify an optimum size, which is a controversial issue due to the definition of how large a municipality is supposed to be in order to be able to provide quality services to the local population (Boyne, 1996b). While large municipalities are more likely to raise revenue due to economies of scale, they also have more costs to deliver services to the local population (Walzer, 1972). On the other hand, it has been demonstrated that "central administrative costs are lower in larger local authorities" (Andrews \& Boyne, 2009, p. 739). Therefore, there is evidence that economies of scale must be treated cautiously in relation to local government performance (Boyne, 1995). From these ideas, we propose the following hypothesis:

H4. Municipal financial performance is positively associated with the size of the population.

\section{Method}

\section{Research sample}

The sample of municipalities was composed of 830 observations. Their characteristics about population size, age of the mayors and GDP per capita are described in Table 1.

Table 1

\section{Descriptive Statistics of the Research Sample}

\begin{tabular}{lcccccc}
\hline & Minimum & Maximum & Mean & SD & Skewness & Std. Error \\
\hline Population size & $884^{\mathrm{a}}$ & $570,042^{\mathrm{b}}$ & $18,173.16$ & $37,230.93$ & 7.44 & 0.09 \\
Mayor's Age & 25 & 85 & 48.52 & 10.06 & 0.38 & 0.09 \\
GDB per capita (R\$ Thousand) & $2.91^{\mathrm{c}}$ & $177.30^{\mathrm{d}}$ & $9.84^{\mathrm{e}}$ & 11.24 & 8.27 & 0.09 \\
\hline
\end{tabular}

Note. Source: data analysis.

${ }^{a}$ Inhabitants of the municipality of Serra da Saudade. ${ }^{b}$ Inhabitants of the municipality of Uberlandia. ${ }^{c}$ GDP per capita of the municipality of Chapada do Norte. ${ }^{\mathrm{d}}$ GDP per capita of the municipality of Confins. ${ }^{\text {e }}$ Roughly corresponds to US $\$ 5,000$. 
In order to test the hypotheses proposed in this study, secondary data was collected from several reliable databases, namely those of the Secretariat of the National Treasury, the Superior Electoral Court, the Ministry of Health and the Brazilian Institute of Geography and Statistics.

\section{Dependent variable}

As dependent variables, we proposed an index to measure the level of self-sufficiency of Brazilian municipalities in terms of wisely managing financial resources (total revenues ratio total expenditures), and, therefore, the level of dependence upon external sources of revenues. In so doing, we collected data for the five-year period from 2004 to 2008. As the mayoral election took place in 2004, we assessed how mayors managed revenue and expenditure over his/her whole period in charge of their respective municipality's administration. As Brazil adopts the strong mayor system of government, mayors are in charge of managing a municipality concerning both political and administrative matters. Worth mentioning is that we cannot at this time update this data for the reason that the last municipal mandate (2008-2012) finished at the end of last year, and data will only be available sometime in the future.

The most representative taxes mayors have control of are property taxes and service taxes, because they vary according to population size, and are, therefore, very likely to reflect economies of scale. As a result, we have chosen property and service taxes as the main sources of revenue the mayor has discretion over and whose appropriate management would increase revenue. Expenditure is the amount of money a municipality has to spend in order to be able to provide services and to manage the whole administrative machine. In this study, we used the total expenditure for representing the effort an administration makes to provide services to the local population.

The three indexes, namely property tax revenue, services tax revenue, and total expenditure, are combined in order to derive an overall measure of dependence upon external sources of revenue, which we labeled as Financial Performance Management Index (FPMI), and calculated by the following formula:

$$
F P M I=\frac{(P T P I+S T P I)}{T E P I}
$$

Where PTPI stands for Property Tax Performance Index, STPI stands for Service Tax Performance Index, and TEPI for Total Expenditure Performance Index. With this formula, we intend to assess each mayor's ability to increase tax revenue in order to meet the total expenditure. Due to the importance of the transfers that municipalities receive from upper-level governments, which is not included in the formula, FPMI is a number between 0 and 1. In this vein, Brazilian municipalities are never able to locally raise a sufficient amount of money to cover their costs. As FPMI approaches zero, the reliance upon these transfers increases and, therefore, the financial situation of the municipality becomes weaker. When that happens, a mayor needs to improve the amount of tax collected locally in order to mitigate dependence as a mean for improving administrative autonomy of the municipality. The interpretation of the index is that the higher the FPMI, the better the municipal financial performance, as the municipality becomes less dependent upon transfers.

\section{Independent variables}

As independent variables, we analyzed mayoral quality and population size, as discussed below.

\section{Mayor's educational background}

The educational background of the mayor is measured by assessing his/her educational level. We coded this variable on an ordinal scale from 1 to 7. In Brazil, and following the system adopted by the Superior Electoral Court, there are seven grades for assessing educational level. The seven 
educational categories range from 1, which stands for able to read and write, up to 7, standing for having completed higher education.

\section{Mayoral quality}

To assess mayoral quality and following the extant knowledge (Avellaneda, 2009), we developed an index combining educational background, age and previous administrative experience. Age is a variable that we collected from the Superior Electoral Court database. For previous administrative experience, we collected the data from the same database, employing a dummy variable (0 and 1): assigning 0 if the mayor were in his or her first mandate, and 1 if he or she had previous administrative experience in public organizations. The following formula represents the calculation of this variable.

$$
M Q=(A \times E B \times P A E)
$$

Where

. $M Q$ : Mayoral Quality

- A: Mayor's Age

. EB: Educational Background

. PAE: Public Administrative Experience

\section{Population size}

Population size was collected from the 2010 Demographic Census (IBGE, 2011). The average population is around 20,000 inhabitants, which indicates that the vast majority of the municipalities have a small population size. The median of the sample indicated a population size of 7,780, which corroborates the small-scale characteristics of the sample. The minimum population was 884 and the maximum was 570,000 inhabitants. Figure 1 illustrates the sample distribution.

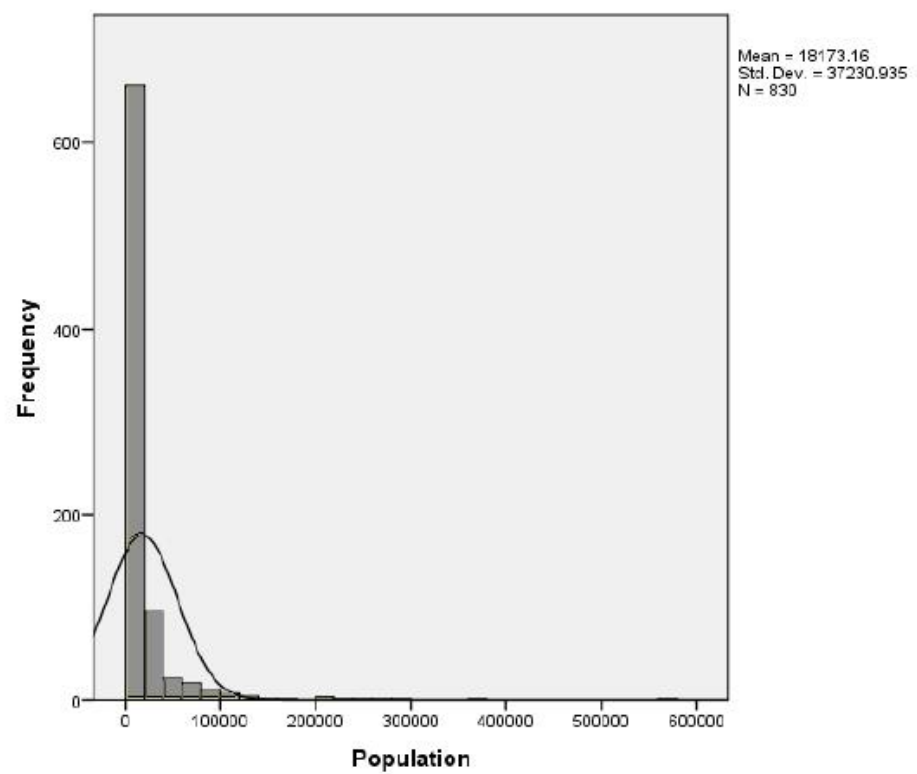

Figure 1. Frequency Distribution of Population Size.

Source: Data Analysis (Instituto Brasileiro de Geografia e Estatística. (2011). Sinopse do censo demográfico de 2010. Recuperado de http://www.ibge.gov.br/home/estatistica/populacao/censo2010). 


\section{Model design}

We structured Equation 3 as the linear model to test the hypotheses presented in section 3 .

$$
F P M I=\beta_{0}+\beta_{1} S+\beta_{2} A+\beta_{3} E B+\beta_{4}(A \times E B \times P A E)
$$

Where

. FPMI: Financial Performance Management Index

- $\quad S$ : Population Size

- A: Mayor's Age

. EB: Educational Background

. PAE: Mayoral Quality

As a matter of clarification, the formula $(\mathrm{A} \times \mathrm{EB} \times \mathrm{PAE})$ is an iteration between these three independents variables, which compose the term MQ. The model presented in Equation 3 was estimated with corrections for linearity, outliers and heteroscedasticity, and became the empirical model stated in Equation 4.

$$
\ln (F P M I)=\beta_{0}+\beta_{1} \ln (S)+\beta_{2} \ln (A)+\beta_{3} E B+\beta_{4}[(A \times E B \times P A E)]
$$

The model in Equation 4 linearizes a data set with exponential structure in addition to provide an interesting interpretation for the regression parameters, as elasticity. The data also showed a high level of heterogeneity, mainly due to population size. We accordingly proceeded with the WLS, where the stipulated weight variable was the population size (S).

\section{Results and Discussion}

According to our findings, $38.6 \%$ of the mayors have higher education, and over $40 \%$ have attended formal higher education schools. For the Property Tax Index $(M=33,859.92, S D=$ 176,992.74), the city that had the lowest capacity for generating revenue from Property Tax collection (lowest slope for the property tax) is the city of Pocrane (-1,197 thousand Brazilian Real), and the highest is the city of Nova Lima (2,288 thousand Brazilian Real). For the Service Tax Index $(M=$ $144,264.28, S D=591,721.73)$, the city that had the lowest capacity for generating revenue from Service Tax collection is also the city of Pocrane (-1,094 thousand Brazilian Real), and the highest is the city of Uberlandia (8,369 thousand Brazilian Real). According to the Total Expenditure Index ( $M$ $=-548,231.33, S D=2,435,097.73)$, the city that had the lowest capacity for reducing expenditure is the city of Juatuba (-23,136 thousand Brazilian Real), and the highest is again the city of Uberlandia (53,477 thousand Brazilian Real).

For the Financial Performance Management Index (FPMI), $(M=0.033$ and $S D=0.009)$, the city that had the best financial performance management capacity (increasing revenue to meet expenditure) is the city of Uberaba $(\mathrm{FPMI}=0.199)$ and the worst is the city of Pocrane (FPMI $=$ $0.018)$.

Another issue that we addressed in this investigation is whether the mayor has previous administrative experience, as indicated by whether this is his/her second political mandate. According to the findings, over $80 \%$ of the elected mayors were in their first mandate, therefore having no previous administrative experience in government. 
To test the empirical model presented in Equation 4, the regression assumptions were considered and verified. Outliers observed for standardized residuals and the missing cases were removed from the analysis, resulting in a valid sample of 776 municipalities. Regarding heteroscedasticity, we performed the Breusch-Pagan test, resulting in $\mathrm{p}<0.01$, thus rejecting the null hypothesis of homoscedasticity. In order to correct the estimates' standard errors, we applied Long and Ervin's (2000) HC3 robust estimation approach, resulting in the final estimates presented in Table 2.

Table 2

Linear Regression Parameters

\begin{tabular}{lcccc}
\hline Parameter & Estimate & Std. Error & Z Value & P Value \\
\hline Intercept & -4.3743 & 0.2431 & -17.9924 & $<0.0001$ \\
Age & -0.0014 & 0.0595 & -0.0229 & 0.98172 \\
Population & 0.0977 & 0.0174 & 5.6220 & $<0.0001$ \\
Educational Level 2 & 0.0234 & 0.0555 & 0.4219 & 0.67312 \\
Educational Level 3 & 0.0062 & 0.0538 & 0.1148 & 0.90858 \\
Educational Level 4 & -0.0372 & 0.0746 & -0.4986 & 0.61803 \\
Educational Level 5 & 0.0179 & 0.0562 & 0.3183 & 0.75025 \\
Educational Level 6 & 0.0263 & 0.0617 & 0.4266 & 0.66968 \\
Educational Level 7 & -0.0098 & 0.0568 & -0.1731 & 0.86254 \\
Age x Educational Level1 x Reelection & 0.0004 & 0.0149 & 0.0296 & 0.97639 \\
Age x Educational Level2 x Reelection & 0.0058 & 0.0063 & 0.9179 & 0.35868 \\
Age x Educational Level3 x Reelection & 0.1128 & 0.0810 & 1.3921 & 0.16390 \\
Age x Educational Level4 x Reelection & 0.0054 & 0.0201 & 0.2704 & 0.78683 \\
Age x Educational Level5 x Reelection & 0.0867 & 0.0425 & 2.0373 & 0.04162 \\
Age x Educational Level6 x Reelection & -0.0083 & 0.0101 & -0.8202 & 0.41208 \\
Age x Educational Level7 x Reelection & 0.0105 & 0.0075 & 1.4035 & 0.16046 \\
\hline
\end{tabular}

Note. Source: data analysis.

To assess the degree of multicollinearity of Equation 4, we used the adjusted GVIF (Adjusted Generalized variance-inflation) (Durant \& Ali, 2013; Wichowsky \& Moynihan, 2008). As the adjusted GVIF was lower than three for all variables and iterations, there was no evidence of multicollinearity in the data. There was no evidence of normality for the residuals according to Kolmogorov-Smirnov test, which gave $p<0.01$. However, despite the absence of normality and due to the valid sample size of 776 municipalities, the Central Limit Theorem can be evoked, providing asymptotically normal estimates for regression model parameters (Williamson, 1963).

The model presented an adjusted $\mathrm{R}^{2}$ of 0.777 . Specifically, $\mathrm{H} 4$ was confirmed since the estimated parameter for the population was significant ( $\mathrm{p}<0.01$ ), showing that an increase of $1 \%$ in population size increases the FPMI value by $0.0977 \%$. Regarding H3, MQ was significant when the mayor's educational level was equal to 5 (i.e., high school), but the remaining hypotheses could not be confirmed since the critical levels achieved were not less than $\mathrm{p}<0.05$.

In order to analyze the factors likely to be regarded as determinant of the financial performance, we conducted a correlation analysis between dependent and independent variables. The evidence indicates there is an association between population size and the possibility to increase revenues in 
terms of property tax $(r=0.69, p<0.01)$. For example, larger cities are more likely to increase property tax and service tax revenue than are smaller cities. This conclusion is compatible with normal assumptions about economies of scale (Shapiro, 1963). The more houses a given city has, the more likely it is to be able to increase the amount of revenue by collecting more property taxes. This line of argument can also be applied to services taxes $(r=0.74, p<0.01)$.

The correlation between the total expenditure management performance index and the population is negative $(\mathrm{r}=-0.46, \mathrm{p}<0.01)$, which indicates that larger municipalities are more likely to reduce costs than are smaller municipalities. This conclusion is congruent with the extant theory (Andrews \& Boyne, 2009). The high correlations make it possible to think about the relevant relationship between the three financial performance management indexes and size as indicated in Table 3.

Table 3

The Relationship between Size and Financial Performance Management Indices

\begin{tabular}{lccccc}
\hline & $\begin{array}{c}\text { Population } \\
\text { Size }\end{array}$ & $\begin{array}{c}\text { Previous } \\
\text { Experience }\end{array}$ & $\begin{array}{c}\text { Property tax } \\
\text { Index }\end{array}$ & $\begin{array}{c}\text { Service tax } \\
\text { Index }\end{array}$ & $\begin{array}{c}\text { Expenditure } \\
\text { Index }\end{array}$ \\
\hline $\begin{array}{l}\text { Population } \\
\text { Size }\end{array}$ & 1.00 & $.19^{* *}$ & $.69^{* *}$ & $.74^{* *}$ & $-.46^{* *}$ \\
Previous & & & & & \\
Experience & 1.00 & $.15^{* *}$ & $.14^{* *}$ & $-.09^{* *}$ \\
$\begin{array}{l}\text { Property tax } \\
\text { Index Modified }\end{array}$ & & & & $.78^{* *}$ & $-.33^{* *}$ \\
$\begin{array}{l}\text { Service tax } \\
\text { Index Modified } \\
\text { Expenditure Index Modified }\end{array}$ & & 1.00 & & $-.40^{* *}$ \\
\hline
\end{tabular}

Note. Source: Data Analysis.f

** Correlation is significant at the 0.01 level (2-tailed).

In terms of mayoral quality as an independent variable, which was measured by educational background, age and previous administrative experience, the evidence gathered in this investigation provides weak support for accepting the hypothesis, as shown in Table 1. This finding indicates that the extant knowledge (Hambrick \& Mason, 1984) has to be taken into account cautiously. The results are statistically significant $(p<0.01)$, but the Pearson's coefficient is near to zero $(p=0.104)$, which indicates a low association between the two variables (Bryman, 2008).

According to the findings, population size can be regarded as an important factor for explaining superior performance. In our research, we found that the larger the municipality, the more likely it is to be able to increase revenue and to reduce expenditures. This is an important finding, as it challenges the fragmentation process a great deal. In terms of financial performance, which was measured by comparing the ability an administration has to increase revenue in order to meet expenditures, larger municipalities demonstrated better performance when compared with small ones. Our findings indicate that there is a strong and positive causal relationship between population size and financial performance. This conclusion also challenges some previous studies that suggested size is not related to performance (Boyne, 1995, 1996b). On the other hand, it also corroborates studies suggesting that small municipalities need to be amalgamated into larger ones in order to improve performance (Andrews \& Boyne, 2009).

Another issue to be considered is a mayor's political ideology. This was a question regarding whether conservative or liberal political ideology could influence performance. In this study, we used 
an indication of left or right wing for several Brazilian political parties. In the comparison between left and right wing administrations, FPMI averages are quite similar, and no statistically significant differences were identified by the nonparametric Mann-Whitney U test. From this, it follows that a mayor's ideology does not really have an impact on financial performance management. A mayor's ability to ensure municipal financial sustainability by making it less dependent upon money from other external sources of revenue is what is important.

\section{Conclusion}

This paper aimed to contribute to performance management literature by providing empirical evidence about the determinant factors likely to influence local government performance, as well as to the discussion about amalgamation versus fragmentation of municipalities. Much has been written about the factors that lead public organizations to high levels of performance, but there is still space for speculation about the impact of managerial issues, such as leadership and mayoral quality, as well as of contextual issues, such as municipal size and wealthy (GDP per head), on local government performance. We tried to shed more light on the situation in this paper by examining some of these issues.

To this end, we examined data about Brazilian municipalities. Brazil is a particularly relevant case due to the huge number of small-scale municipalities that are the result of a fragmentation process created by the 1988 Federal Constitution. Besides having low populations, they also have fragile administrative structures that rely heavily upon transfers from upper-level governments as their main sources of revenue. As a dependent variable, we employed an index in which all locally collected revenues are compared with total expenditures in order to assess the local capacity an administration has to use to avoid dependence upon external sources of revenue. The independent variables were mayoral quality and population size.

The theories that underpin this study were mainly related to the determinants of performance in public organizations, which is well established in the public management domain. According to these theories, resources, regulation, market structure, organization and management are the main sources of performance. In this paper, we focused on managerial and contextual aspects of public organizations, namely mayoral quality, political ideology and municipality population size as feasible explanations for understanding superior financial performance. We contend that municipality size and some aspects of mayoral quality can be used to explain this phenomenon.

Our main findings relate to the conclusion that larger cities are more likely than smaller cities to manage revenue and expenditure well. In such cases, mayors have little power to improve financial performance due to reliance on transfers from upper-level governments, specifically the Federal and State Governments in Brazil. As recent history has witnessed the creation of new, very small municipalities, we can conclude that they are not sustainable in terms of finance. Instead of trying to become sustainable, these new local authorities are becoming a burden on both Federal and State Governments.

The other conclusion of this investigation is about mayoral background. In spite of the low level of statistical association between financial performance and mayoral quality (a composite of age, educational background and previous administrative experience), the level of statistical association is a little higher when looking at the educational background alone. This fact indicates that local government managers need to be better prepared in order to fulfill their responsibilities while in charge of the municipality's duties. In terms of political ideology, the evidence gathered in this investigation does not imply that this is likely to be regarded as an issue in terms of financial performance. 
From the evidence collected, we can conclude that size is an important and controversial issue in the local government domain. We also concluded that mayoral quality is likely to affect performance, and that previous administrative experience somehow affects managerial performance. The evidence provided here corroborates many of the theories that can be found in extant public management literature, as well as in financial management literature. However, it also challenges a great deal the idea that small municipalities are better than larger ones, at least when considering the ability to raise money locally and reduce costs. If on one hand we contend that there are some determinant factors likely to influence local government financial performance - such as larger cities being more likely to increase tax collection locally and thus become less dependent on transfers from upper-level government - on the other hand the flypaper effect is evidence that holding local governments dependent upon federal and state transfers is a deliberate strategy. The results presented in this paper also challenge, to a considerable extent, the fragmentation practice being carried out in some countries consisting of creating new municipalities by disaggregating larger ones into smaller units.

For future investigations, we suggest comparing the strong-mayor form of local government with others, for instance the American council-manager and the British committee-leader forms of local government. We assumed that mayoral quality gets dispersed within the amount of activities a mayor gets involved in, acting as both political leader and city manager. We also suggest having a deeper look at the financial performance definition itself. In this study, we used an index comparing the ability to create revenues for meeting expenditures. However, and since we used total expenditures, the concept of acquiring resources in order to keep the administration running may have been overlooked. Total expenditures could be split into administrative expenditures, personnel expenditures, investments, bureaucracy, and other types of expenditures. These concepts will help provide a more accurate view of the way municipalities spend money.

\section{References}

Andrews, R., \& Boyne, G. A. (2009). Size structure and administrative overheads: an empirical analysis of English local authorities. Urban Studies, 46(4), 739-759. doi: $10.1177 / 0042098009102127$

Andrews, R., Boyne, G. A., \& Walker, R. M. (2011). Dimensions of publicness and organizational performance: a review of the evidence. Journal of Public Administration Research and Theory, 21(Suppl. 3), i301-i319. doi: 10.1093/jopart/mur026

Avellaneda, C. N. (2009). Municipal performance: does mayoral quality matter? Journal of Public Administration Research and Theory, 19(2), 285-312. doi: 10.1093/jopart/mun001

Bailey, S. J., \& Connolly, S. (1998). The flypaper effect: identifying areas for further research. Public Choice, 95(3/4), 335-361. doi: 10.1023/A:1005053921709

Besley, T., Montalvo, J. G., \& Reynal-Querol, M. (2011). Do educated leaders matter? The Economic Journal, 121(554), F205-227. doi: 10.1111/j.1468-0297.2011.02448.x

Bohte, J. (2001). School bureaucracy and student performance at the local level. Public Administration Review, 61(1), 92-99. doi: 10.1111/0033-3352.00008

Borukhov, E. (1975). On the urban agglomeration and economic efficiency: comment. Economic Development and Cultural Change, 24(1), 199-205.

Boyne, G. (1995). Population size and economies of scale in local government. Policy and Politics, 23(3), 213-222. doi: 10.1332/030557395782453446 
Boyne, G. (1996a). Scale, performance and local government reorganization: an analysis of the nonmetropolitan districts. Public Money \& Management, 16(3), 55-60. doi: $10.1080 / 09540969609387934$

Boyne, G. (1996b). Scale, performance and the new public management: an empirical analysis of local authorities services. Journal of Management Studies, 33(6), 809-826. doi: 10.1111/j.14676486.1996.tb00173.x

Boyne, G. A. (2003). Sources of public service improvement: a critical review and research agenda. Journal of Public Administration Research and Theory, 13(3), 367-394. doi: 10.1093/jopart/mug027

Brewer, G. A. (2005). In the eye of the storm: frontline supervisors and federal agency performance. Journal of Public Administration Research and Theory, 15(4), 505-527. doi: 10.1093/jopart/mui031

Bryman, A. (2008). Social research methods (3rd ed.). Oxford: Oxford University Press.

Carey, M., Srinivasan, A., \& Strauss, R. P. (1996). Optimal consolidation of municipalities: an analysis of alternative designs. Socio-Economic Planning Sciences, 30(2), 103-119. doi: $10.1016 / 0038-0121(95) 00022-4$

Dahlby, B. (2011). Too many municipalities? Revista Brasileira de Economia, 65(1), 23-32. doi: $10.1590 / \mathrm{S} 0034-71402011000100002$

Durant, R. F., \& Ali, S. B. (2013). Repositioning American public administration? citizen estrangement, administrative reform, and the disarticulated state. Public Administration Review, 73(2), 278-289. doi: 10.1111/j.1540-6210.2012.02646.x

Fenno, R. F. (1966). The power of the purse: appropriations politics in Congress. Boston: Little Brown.

Fiedler, F. E. (1986). The contribution of cognitive resources and leader behavior to organizational performance. Journal of Applied Social Psychology, 16(6), 532-548. doi: 10.1111/j.15591816.1986.tb01157.x

Hambrick, D. C., \& Mason, P. A. (1984). Upper echelons: the organization as a reflection of its top managers. Academy of Management Review, 9(2), 193-206. doi: 10.5465/AMR.1984.4277628

Hamilton, J. H. (1986). The flypaper effect and the deadweight loss from taxation. Journal of Urban Economics, 19(2), 148-155. doi: 10.1016/0094-1190(86)90036-7

Hines, J. R., \& Thaler, R. H. (1995). The flypaper effect. Journal of Economic Perspectives, 9(4), $217-$ 226. doi: $10.1257 /$ jep.9.4.217

Hoene, C., \& Pagano, M. (2008). Cities and state fiscal structure. Washington, DC: National League of Cities.

Hood, C. (1991). A public management for all seasons? Public Administration, 69(1), 3-19. doi: 10.1111/j.1467-9299.1991.tb00779.x

Inman, R. P. (2008). The flypaper effect [Working Paper N. w14579]. Social Science Research Network. Retrieved from http://ssrn.com/abstract $=1320825$

Instituto Brasileiro de Geografia e Estatística. (2011). Sinopse do censo demográfico de 2010. Recuperado de http://www.ibge.gov.br/home/estatistica/populacao/censo2010 
Kloot, L. (1999). Performance measurement and accountability in Victorian local government. International Journal of Public Sector Management, 12(7), 565-584. doi: $10.1108 / 09513559910308039$

Lynn, L. E. (1996). Public management as art, science and profession. Chatham: Chatham House.

Martell, C. R. (2008). Fiscal institutions of Brazilian municipal borrowing. Public Administration and Development, 28(1), 30-41. doi: 10.1002/pad.474

Mattos, E., Rocha, F., \& Arvate, P. (2011). Flypaper effect revisited: evidence for tax collection efficiency in Brazilian municipalities. Estudos Econômicos, 41(2), 239-267. doi: 10.1590/S0101-41612011000200002

Meier, K. J., \& Keiser, L. R. (1996). Public administration as a science of the artificial: a methodology for prescription. Public Administration Review, 56(5), 459-466. doi: 10.2307/977045

Mogues, T., \& Benin, S. (2012). Do external grants to district governments discourage own revenue generation? A look at local public finance dynamics in ghana. World Development, 40(5), 10541067. doi: 10.1016/j.worlddev.2011.12.001

Mouritzen, P. E., \& Svara, J. H. (2002). Leadership at the Apex: politicians and administrators in western local governments. Pittsburgh: University of Pittsburgh Press.

Moynihan, D. P., \& Pandey, S. K. (2005). Testing how management matters in an era of government by performance management. Journal of Public Administration Research and Theory, 15(3), 421-439. doi: 10.1093/jopart/mui016

O'Toole, L. J., Jr., \& Meier, K. J. (1999). Modeling the impact of public management: implications of structural context. J Public Adm Res Theory, 9(4), 505-526.

Ogden, S., \& Watson, R. (1999). Corporate performance and stakeholder management: balancing shareholder and customer interests in the U.K. privatized water industry. Academy of Management Journal, 42(5), 526-538. doi: 10.2307/256974

Pfeffer, J., \& Salancik, G. R. (2003). The External Control of Organizations: a resource dependence perspective. Stanford: Stanford Business Books.

Rainey, H. G., \& Steinbauer, P. (1999). Galloping elephants: developing elements of a theory of effective government organizations. Journal of Public Administration Research and Theory, $9(1), 1-32$.

Selcher, W. A. (1998). The politics of decentralized federalism, national diversification, and regionalism in Brazil. Journal of Interamerican Studies and World Affairs, 40(4), 25-50. doi: 10.1111/j.1548-2456.1998.tb00072.x

Shapiro, H. (1963). Economies of scale and local government finance. Land Economics, 39(2), 175186. doi: $10.2307 / 3144753$

Stafford, H. A. (1963). The functional bases of small towns. Economic Geography, 39(2), 165-175. doi: $10.2307 / 142509$

Stanwick, P. A., \& Stanwick, S. D. (1998). The relationship between corporate social performance and organizational size, financial performance, and environmental performance: an empirical examination. Journal of Business Ethics, 17(2), 195-204. doi: 10.1023/A:1005784421547

Taylor, R. N. (1975). Age and experience as determinants of managerial information processing and decision making performance. Academy of Management Journal, 18(1), 74-81. doi: $10.2307 / 255626$ 
Vilkinas, T., Cartan, G., \& Piron, S. (1994). Performance determinants for senior managers: rhetoric or reality? Leadership \& Organization Development Journal, 15(6), 24-32. doi: $10.1108 / 01437739410066090$

Waddock, S., \& Smith, N. (2000). Corporate responsibility audits: doing well by doing good. Sloan Management Review, 41(2), 75-83.

Walzer, N. (1972). Economies of scale and municipal police services: the illinois experience. The Review of Economics and Statistics, 54(4), 431-438. doi: 10.2307/1924570

Watts, R. L. (1998). Federalims, federal political systems, and federations. Annual Review of Political Science, 1, 117-137. doi: 10.1146/annurev.polisci.1.1.117

Whitney, M. (2013). Fate of the states: the new geography of American prosperity. New York: Portfolio/Penguin.

Wichowsky, A., \& Moynihan, D. P. (2008). Measuring how administration shapes citizenship: a policy feedback perspective on performance management. Public Administration Review, 68(5), 908-920. doi: 10.1111/j.1540-6210.2008.00931.x

Williamson, O. E. (1963). Managerial discretion and business behavior. The American Economic Review, 53(5), 1032-1057. doi: 10.2307/1812047

Zafra-Gómez, J. L., López-Hernández, A. M., \& Hernández-Bastida, A. (2009). Developing a model to measure financial condition in local government: evaluating service quality and minimizing the effects of the socioeconomic environment: an application to spanish municipalities. The American Review of Public Administration, 39(4), 425-449. doi: 10.1177/0275074008320710 